\title{
Modeling the potential distribution of Epiphyllum phyllanthus (L.) Haw. under future climate scenarios in the Caatinga biome
}

\author{
ARNÓBIO M.B. CAVALCANTE, ARYBERG S. DUARTE \& JEAN PIERRE H.B. OMETTO
}

\begin{abstract}
The climate change projections for the Caatinga biome this century are for an increase in temperature and reduction in rainfall, leading to aridization and plant cover dominated by Cactaceae. The objective of this study was to model the potential distribution of Epiphyllum phyllanthus (L.) Haw., a cactus that is native to the Caatinga biome, considering two possible future climate scenarios, to assess this species' spatiotemporal response to these climate change, and thus to evaluate the need or not for conservation measures. For this purpose, we obtained biogeographic information on the target species from biodiversity databases, choosing nine environmental variables and applying the MaxEnt algorithm. We considered the time intervals 2041-2060 and 2061-2080, centered on 2050 and 2070, respectively, and the greenhouse gas scenarios RCP4.5 and 8.5. For all the scenarios considered, the models generated for 2050 and 2070 projected drastic contraction (greater than $80 \%$ ) for the areas of potential occurrence of the species in relation to the present potential. The remaining areas were found to be concentrated in the northern portion of the biome, specifically in the northern part of the state of Ceará, which has particular characteristics.
\end{abstract}

Key words: Cactaceae, climate change, conservation, epiphytic cactus, maxent.

\section{INTRODUCTION}

The theme of climate change associated with global warming has gained importance among the international scientific community due to its immediate and potential future impacts on the quality of human life, as well as on biodiversity. The evidence of the occurrence of this phenomenon is ample, provided by a huge number of scientific works in recent years. Of particular note is theQuinto Relatório de Avaliação sobre Mudanças Climáticas, (AR5), prepared by the Intergovernmental PPainel Intergovernamental sobre Mudanças Climáticas, which confirmed the occurrence of global climate changes with impacts on all the continents and oceans (IPCC 2014a, b, c).
In Brazil, the leading reference is the Primeiro Relatório de Avaliação Nacional sobre Mudanças Climáticas (First National Assessment Report on Climate Change), prepared by the Painel Brasileiro de Mudanças Climáticas (Brazilian Panel on Climate Change), which predicts an increase in air temperature and greater frequency of extreme events in the country (PBMC 2014a, b). In particular for the Northeast region, the works of Marengo (2008, 2014), Sales et al. (2015), Lacerda et al. (2016) and Marengo et al. (2017) stand out, with projections, considering a pessimistic scenario, of a trend for an increase in the number of months with water deficit (aridization).

For the Caatinga biome, mainly inserted in the Northeast region, the latest projection is for 
an increase in average temperature of up to 4,5 ${ }^{\circ} \mathrm{C}$ and decline in precipitation of as much as $50 \%$ by the end of this century (Brasil 2016a). With respect to the biological component, particularly vegetation and flora, the forecast is for substitution of the present vegetation with plants suited to more arid environments, with predominance of cacti (Marengo 2007, 2008). With respect to flora, mention can be made of the review of Santos et al. (2014), pointing to the future predominance of species native to the Caatinga biome that are physically equipped to face extreme drought events, and the review of Albuquerque et al. (2012), indicating that rainfall and temperature, in that order, are the main physical elements responsible for triggering and ending biological processes (phenological, pollination, reproduction etc.) in Caatinga species, which will thus be affected by climate change. Both reviews also point to a large gap in knowledge of the effects of climate change on the vegetation and flora.

The fact is that climatic changes are and will continue to affect the Caatinga biome, and the studies currently available are insufficient, in light of the number of spermatophyte species existing there, 5344 (Giullieti et al. 2006), for a reasonably precise evaluation of the effects on plant species in the present and future. This insufficiency is cause for concern, since the Quinto Relatório Nacional para a Convenção Sobre Diversidade Biológica (Fifth National Biodiversity Report for Brazil) (Brasil 2016b) classified the Caatinga biome as the fourth most devastated biome in the country, with only $53.4 \%$ of native vegetation remaining. Furthermore, the Caatinga was recently included on the list of regions in the world that are most ecologically sensitive to climate variability, together with the Arctic tundra, parts of the boreal forest range and tropical forests, among others (Seddon et al. 2016).
To summarize, the climatic changes under way, causing a tendency for aridization and alteration in the composition and structure of vegetation, combined with the anthropogenic destruction and natural vulnerability, lead to an expectation of total collapse of the diversity of plants in the Caatinga biome by the end of this century, unless effective preventive action is taken. Therefore, in response to this apocalyptic prediction for the future, it is urgent to conduct studies to improve comprehension of the possible effects of climate change on the plant species of the Caatinga biome.

For this purpose, numerical models exist to attain this ecological comprehension and predict the distribution of species in a landscape undergoing transformation. These models are variously known as species distribution models, bioclimatic models or ecological niche models. They generate probabilistic forecasts of where a species may or may not be present, and the projected area represents the potential distribution of the target species based on the environmental predictors used in the modeling (Pearson \& Dawson 2003, Guisan \& Thuiller 2005, Elith \& Leathwick 2009).

This approach has been applied successfully to predict the potential occurrence of native species (Téllez-Valdés \& Vila-Aranda 2003, Butler \& Stabler 2012, Yang et al. 2013) and invasive plants (Peterson et al. 2003, Beaumont et al. 2009, Stohlgren et al. 2010), as well as to assess the future effects of climate change on the geographic distribution of species of different taxonomic groups (Araújo et al. 2006, OgawaOnishi et al. 2010, Cortes et al. 2014).

Despite the existence of modeling errors and the complexity of the natural systems involved, which impose limits on the reliability of the forecasts, species distribution modeling is a common tool used in studies to predict biodiversity (Bellard et al. 2012), by supplying 
an initial approximation of the (potentially dramatic) impacts of climate change on the distribution of species (Pearson \& Dawson 2003).

In this context, the objective of this study was to model the potential distribution of Epiphyllum phyllanthus, a true epiphytic cactus that is native to the Caatinga biome, considering two possible future climate scenarios, with respect to its spatio-temporal response, and consequently to assess whether or not adaptive measures are necessary.

\section{MATERIALS AND METHODS}

\section{Study area}

The area of the background points and the area where the model was projected are the same, corresponding to the Caatinga biome, nearly all of which is located in Brazil's Northeast region (Fig. 1), with an area of $844,453 \mathrm{~km}^{2}$ or $10 \%$ of the nation's territory (MMA 2017). Because of its location entirely between the Equator and Tropic of Capricorn ( $3^{\circ}$ to $18^{\circ}$ South latitude), the biome receives intense sunlight throughout its territory year round. The temperatures are high with little spatial or temporal variation, with annual averages between 25 and $30^{\circ} \mathrm{C}$ and few degrees of difference between the means in the coolest and hottest months (Sampaio 2003). The water availability, unlike temperature, is highly variable in time and space, with erratic rainfall, concentrated in a few months, and with wet years interspersed irregularly with dry years (Sampaio 2010). The yearly rainfall fluctuates between just under $300 \mathrm{~mm}$ to slightly above $1,000 \mathrm{~mm}$ (Reddy 1983). The terrain in the region is also varied, with formations such as large depressions, sedimentary plateaus and residual massifs. Some of these plateaus and massifs reach elevations of more than 1,000 meters, and due to orographic lifting they are moister on the windward side, causing different climate conditions than those in the surrounding areas at lower elevations, where the conditions are semiarid (Cavalcante 2005).

The prevailing climate in the Caatinga biome is semiarid, so its flora presents adaptations to deal with water deficiency (deciduous leaves, succulence, thorns and spines, typically small size of bushes and trees, etc.) and significant endemism (Rodal \& Sampaio 2002). Additionally, the biome has small enclaves of other types of vegetation such as mountain forests, savannas and rocky fields (Giulietti et al. 2006).

This plurality of vegetation types is composed of over 200 botanical families, of which Cactaceae is one of the most important. Besides the taxonomic richness, including 23 general and 91 endemic native species (Flora do Brasil 2017), the family also performs important economic, social and environmental roles (Taylor \& Zappi 2004, Cavalcante et al. 2013, Cavalcante \& Vasconcelos 2016). Indeed, cacti are emblematic not only of the biome, but the entire Northeast region of Brazil.

\section{Species selected}

Of the 91 native cactus species present in the Caatinga biome, seven are true epiphytic cacti (Flora do Brasil 2017). Among these, we selected Epiphyllum phyllantus (L.) Haw. to model the geographic distribution. This cactus is not endangered in Brazil (Martinelli \& Moraes 2013) and mainly occurs from sea level to altitude up to 1,300 meters. It is the most widespread cactus species in eastern Brazil, commonly present in wetter regions (Taylor \& Zappi 2004). The choice was tied to the satisfactory biological and ecological knowledge about the species, and particularly the adequate quantity and quality of the biotic data required by the algorithm. 


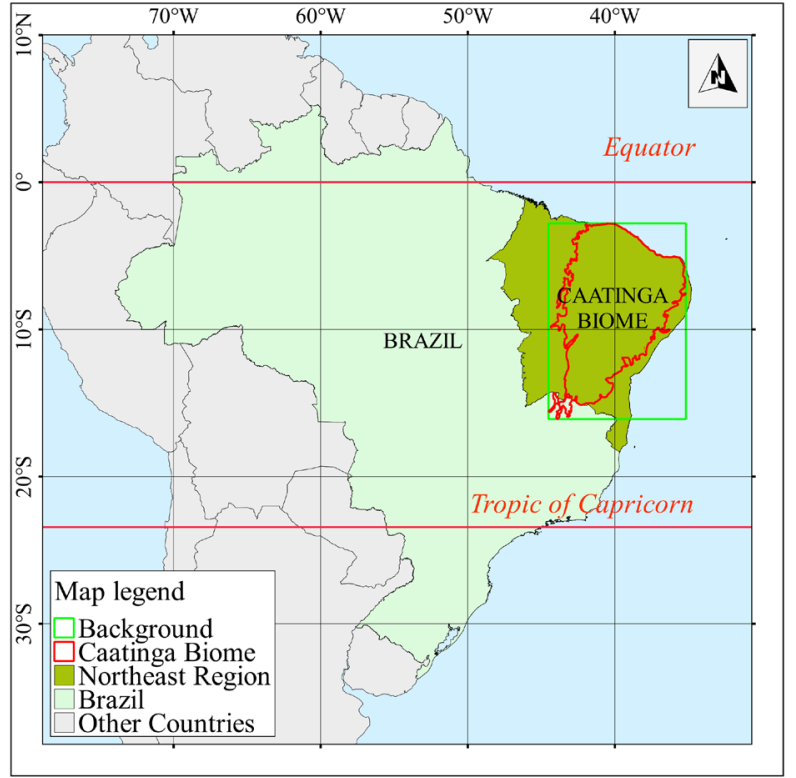

Figure 1. Location of the Caatinga biome.

\section{Modeling}

The records of the presence of E. phyllantus in the form of decimal geographic coordinates were obtained from two online databases, the Sistema Global de Informação sobre Biodiversidade (2017) GBIF (2017) and SpeciesLink - SPLINK (2016). We did not use records of the absence of the species. Therefore, a total of 53 georeferenced presence points were observed in the Caatinga biome and retrieved. All the retrieved points were checked one at a time in sequence, for removal of points with incorrect geographic coordinates, records located in urban areas and duplicate records from the same local, as described by Dalapicolla (2016). This left reliable and good-quality data consisting of 30 records of presence. These points were plotted on an altitude map of the terrain in the Caatinga biome (Fig. 2).

With respect to the dimension of the set of environmental variables for use in the modeling, we first sought to select variables revealing dominant control and associated with the particularities of the target species and area studied. For this purpose, we considered the effectiveness of the environmental variable in triggering and concluding physiological events (flowering, pollination, reproduction and dispersion), as well as spatially arranging plants in the Caatinga biome. This was achieved by consulting the specialized literature (Ab'Sáber 2003, Taylor \& Zappi 2004, Cavalcante 2005, Sampaio 2010, Albuquerque et al. 2012, Santos et al. 2014). Therefore, we selected climatic and topographic variables. We did not include other variables, such as land use, type of soil and biotic interaction.

For the topographic variables (3), elevation, declivity and orientation of slopes, the data were obtained from http://eros.usgs.gov, while the climatic variables temperature (11) and precipitation (8) were downloaded from http:// worldclim.org (v. 1.4) with spatial resolution of 30 seconds $(\sim 1 \mathrm{~km})$. Then we reduced this initial set of 22 environmental variables to just nine by means of Principal Component Analysis

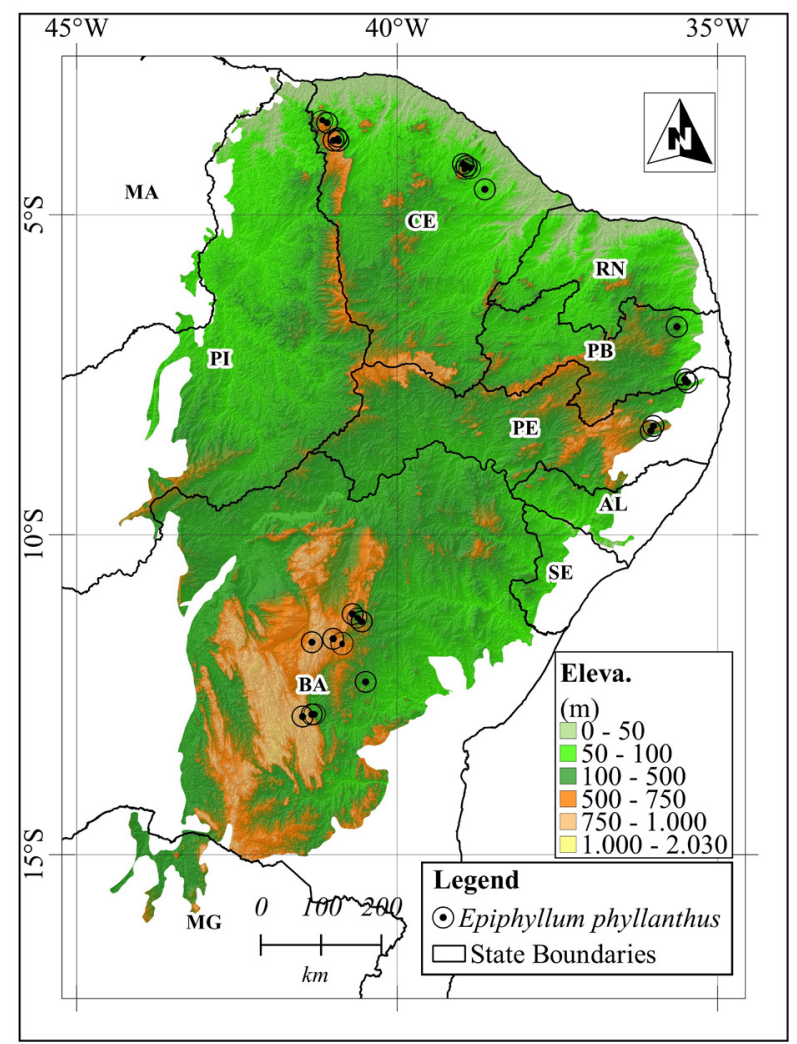

Figure 2. Current distribution of Epiphyllum phyllantus in the Caatinga biome. 
(PCA), considering a maximum correlation level between the environmental variables of 0.7 (Warren et al. 2014, Dalapicolla 2016). Therefore, based on the ecophysiological relations of the target species and supported by a statistical tool (PCA), we reduced the mass of data with the least possible loss of information, and consequently worked with environmental variables having greater independence and stronger power to contribute to the distribution of the target species. The resulting environmental variables and their respective codes were: Bio2 - daily mean amplitude; Bio3 - isothermality; Bio5 maximum temperature in the hottest month; Bio12 - annual precipitation; Bio14 - precipitation in the driest month; Bio18 - precipitation in the hottest quarter; ELE - elevation; DEC - declivity; and DIR - direction of slopes. We also used the jackknife test to calculate the relative importance of these variables for the distribution model of E. phyllantus.

For future climate conditions, we used data from the global model HadGEM2-ES (Hadley Global Environment Model 2 - Earth System), aligned with the time intervals 2041-2060 and 2061-2080, with respective centers in 2050 and 2070 (Hijmans et al. 2005), and the greenhouse gas scenarios RCP 4.5 and 8.5 (Van Vuuren et al. 2011). The current climate conditions (those taken as the baseline) corresponded to data observed in the period from 1961 to 1990 (op. cit.).

The programs used in this work were Maxent 3.4.1 (http://biodiversityinformatics. amnh.org/open_source/maxent/) and QGIS 2.18 (http://www.qgis.org). Therefore, a total of 18 simulations of the Maxent algorithm were produced for each time interval-scenario, from which we extracted a mean of the simulations to obtain the final model. The area under the ROC curve (AUC) was calculated to validate the quality of the final models generated (Phillips
2006, Beaumont et al. 2009), with the following classification: $A U C<0.80$ is a poor or null model; $0.80<$ AUC $<0.90$ is fair; $0.90<$ AUC $<0.95$ is good and $0.95<$ AUC 1.0 is excellent (Thuiller et al. 2006). Furthermore, using a GIS, we calculated the extension of the areas originally occupied, extended and contracted, containing the target species, starting from the present as the climate changes.

\section{RESULTS}

Considering the set of nine environmental variables with greatest independence and power to contribute to the distribution of the target species, the jackknife test indicated that declivity (DEC), precipitation in the driest month (Bio14), isothermality (Bio3) and maximum temperature in the hottest month (Bio5) were the most important environmental variables related to modeling the potential distribution of E. phyllantus, with contributions higher than $18 \%$. In turn, the variables that contributed the least in this respect were annual precipitation (Bio12), direction of the slope (DIR), daily mean amplitude (Bio2) and precipitation in the hottest quarter (Bio18), with contributions lower than $2 \%$. The variable elevation (ELE) was intermediate, with approximate contribution of $7 \%$.

A total of five final Maxent models were produced for the potential distribution of $E$. phyllantus: one current distribution model (Figs. $3 a$ and 4a), two models for 2050 (Fig. 3b, c) and two models for 2070 (Fig. 4b, c). The final models had "good" precision, with $0.90 \mathrm{e}<\mathrm{AUC}<0.95$ (Table I).

The current distribution model revealed the existence of a range of probabilities of the occurrence of $E$. phyllantus, from zero (absence) to 1,00 (presence) in the Caatinga biome (Figs. $3 \mathrm{a}$ and $4 \mathrm{a}$ ). It also indicated areas 
with different potentials, suggesting other geographic areas besides those with presentday records of occurrence. Taken together, the areas with high potential for occurrence (> 0.75 chance) amounted to $24.295,03 \mathrm{~km}^{2}$ (Table II), corresponding to $2.9 \%$ of the biome's area $\left(844.453 \mathrm{~km}^{2}\right)$. The states of Bahia and Ceará accounted for most of these areas.

For the future, the four distribution models produced (Figs. 3b, c and 4b, c) showed differences in the potential distribution of $E$. phyllantus, compared to each other and with the current distribution model (Figs. 3a and 4a). Despite the differences in the biogeographic arrangements, the potential distribution models for 2050 (RCP4.5 and 8.5) and 2070 (RCP4.5 and 8.5) all indicated a contraction of the most suitable areas for the target species with passage of time until the end of the century.
The bioclimatic modeling with the climate changes included allowed identifying distinct future scenarios for the potential distribution of E. phyllantus in relation to today's conditions. In the first scenario, supposedly one of lesser impact through temperature increase and reduction of rainfall, corresponding approximately to 2050/ RCP4.5 (Fig. 3b), there was substantial contraction of the areas with high potential $(>0.75-1.00)$ in about $20.000 \mathrm{~km}^{2}$, i.e., involving losses of $84 \%$ of the original area (Table $\|$ ). In relation to the second (intermediate) scenario, corresponding simultaneously to 2070/RCP4.5 (Fig. 3C) and 2050/RCP8.5 (Fig. 4b), the two models indicated even stronger contraction, with losses of $91 \%$ and $90 \%$ in high potential areas, respectively (Table II). In the third and last scenario, corresponding approximately to 2070/RCP8.5 (Fig. 4C), there was a drastic, even catastrophic, reduction of

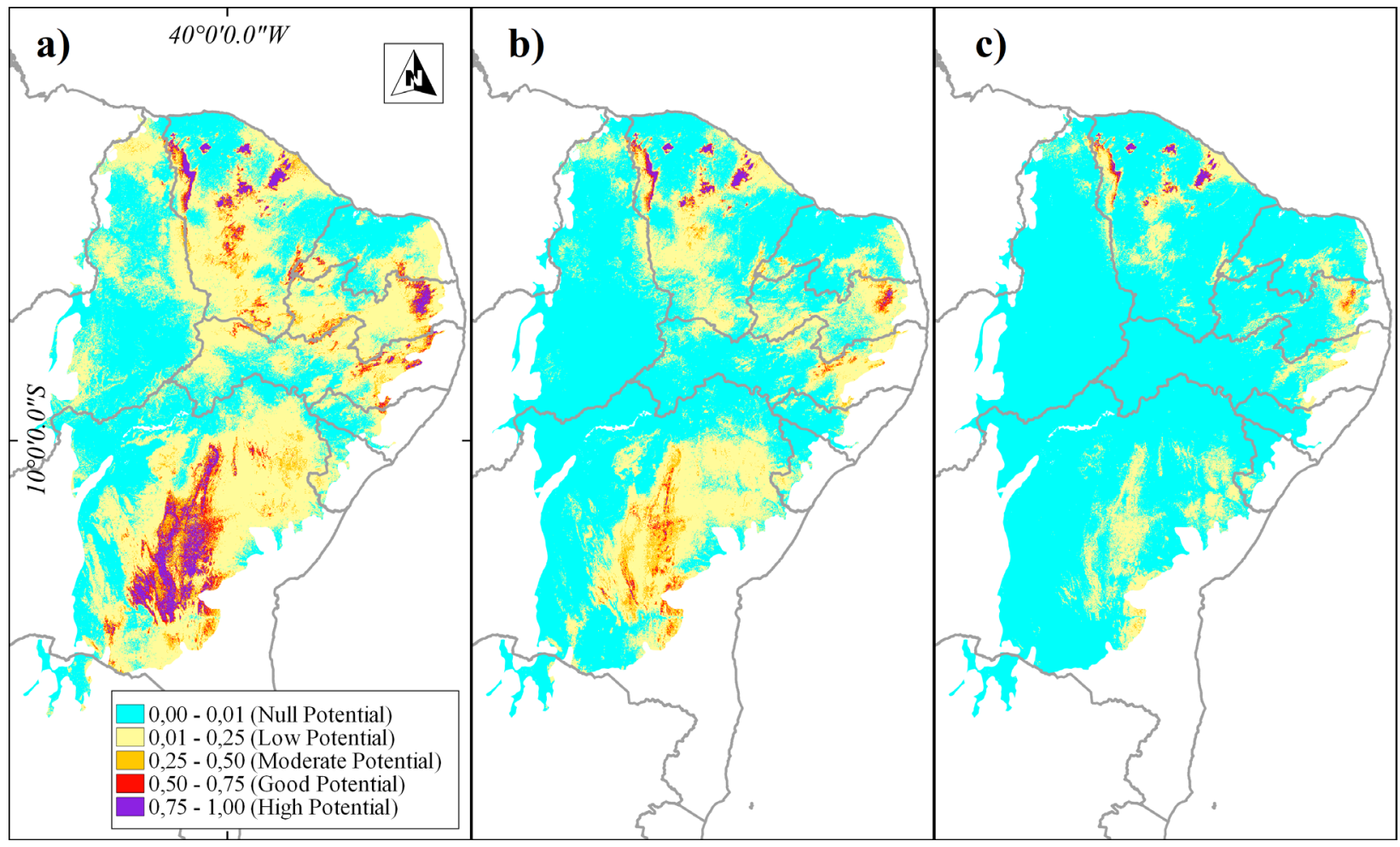

Figure 3. Current spatial distribution (a) and spaces projected for 2050 (b) and 2070 (c) in scenario RCP4.5 for Epiphyllum phyllantus in the Caatinga biome. 
all the areas with greater chances of occurrence of the species (>0.50), especially areas of high potential, where losses were indicated of $94 \%$ in relation to the original conditions. Thus, for the three future scenarios in reference to the current conditions, the areas of high potential projected for the presence of $E$. phyllantus in the Caatinga biome declined drastically, indicating that in the worst of the scenarios, 2070/RCP8.5 (Fig. 4C), by the end of the century the target species will be found only in an area of roughly $1,000 \mathrm{~km}^{2}$, located in the northernmost portion of the biome, nearly all in the northern part of ceará.

\section{DISCUSSION}

The nine environmental variables selected for being important to model the distribution of the target species (Bio2 - daily mean amplitude; Bio3
- isothermality; Bio5 - maximum temperature in the hottest month; Bio12 - annual precipitation; Bio14 - precipitation in the driest month; Bio18 - precipitation in the hottest quarter; ELE elevation; DEC - declivity; and DIR - direction) not only provided a mixture of averages, extremes and seasonality, they also reflected the availability of water from rain or dew. E. phyllantus is a true epiphytic cactus whose stalk stores little water, so that it only uses water from rain or dew. Besides requiring a robust support plant, preferably a tree, it needs a regular supply of water (rain or dew) for establishment. Albuquerque et al. (2012) stressed that water is the main factor controlling plants in the Caatinga biome, followed by temperature, photoperiod and soil.

The present and projected areas of good to high potential distribution of E. phyllantus (> 0.50) according to the model were mainly

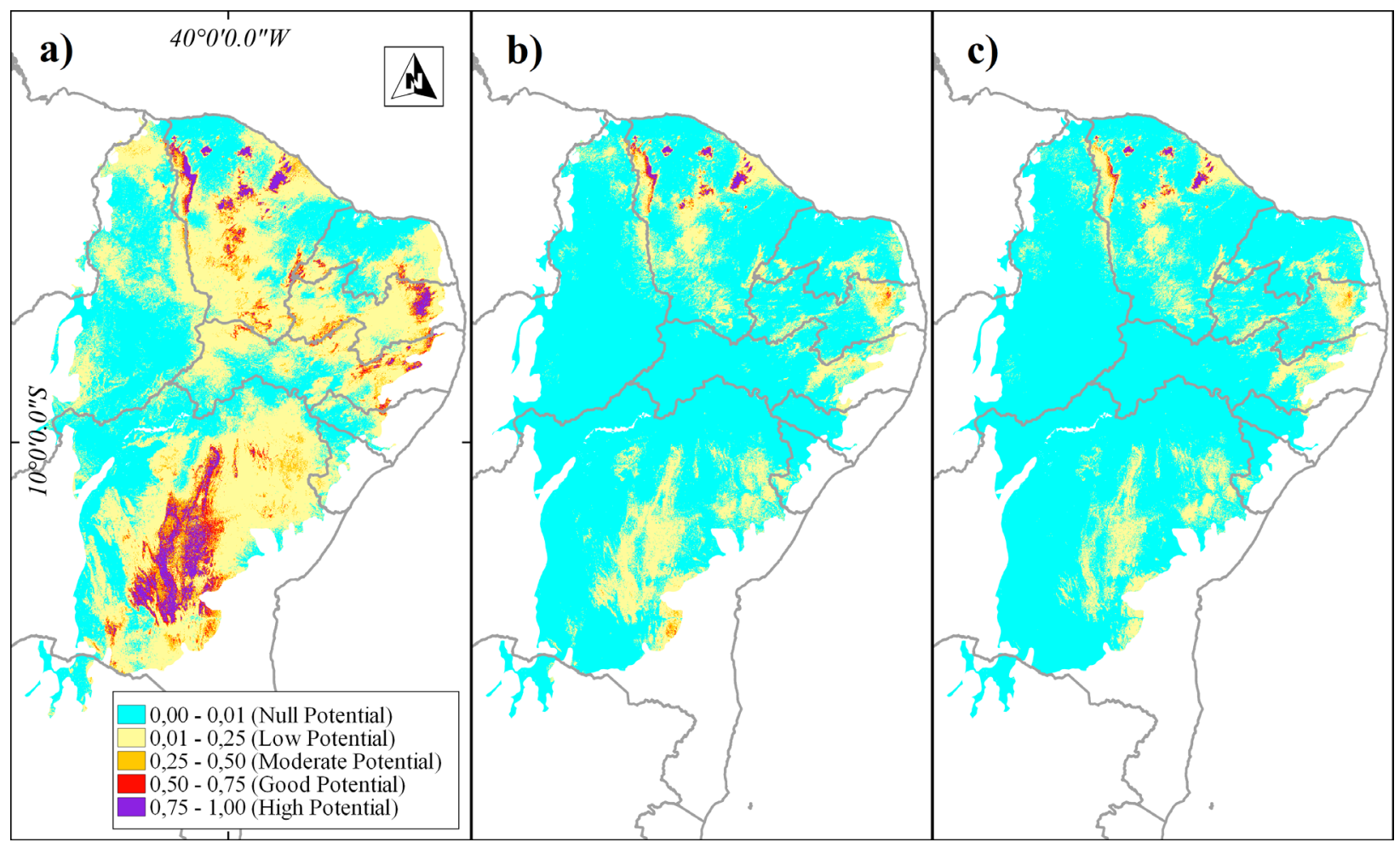

Figure 4. Current spatial distribution (a) and spaces projected for 2050 (b) and 2070 (c) in scenario RCP8.5 for Epiphyllum phyllantus in the Caatinga biome. 
Table I. AUC values of the final models.

\begin{tabular}{|c|c|c|}
\hline Scenarios & Time Intervals & AUC \\
\hline \multirow{2}{*}{ Current } & $1961-1990$ (baseline) & 0.93 \\
\hline \multirow{2}{*}{ RCP4.5 } & & 0.92 \\
\hline \multirow{2}{*}{ RCP8.5 } & $2041-2060(2050)$ & 0.93 \\
\hline & $2061-2080(2070)$ & \\
\hline & & 0.92 \\
\hline
\end{tabular}

Table II. Absolute and relative values of areas with high potential occurrence $(>0.75)$.

\begin{tabular}{|c|c|c|c|c|c|}
\hline Scenario & Current & \multicolumn{2}{|c|}{ RCP4.5 } & \multicolumn{2}{c|}{ RCP8.5 } \\
\hline $\begin{array}{c}\text { Interval } \\
\text { (years) }\end{array}$ & $\begin{array}{c}1961-1990 \\
\text { (baseline) }\end{array}$ & $2041-2060(2050)$ & $2061-2080(2070)$ & $2041-2060(2050)$ & $\begin{array}{c}2061-2080 \\
(2070)\end{array}$ \\
\hline $\begin{array}{c}\text { Area } \\
\left(\mathrm{km}^{2}\right)\end{array}$ & 24.295 .03 & 3.817 .81 & 2.092 .49 & 2.391 .16 & 1.375 .89 \\
\hline $\begin{array}{c}\text { Contraction } \\
(\%)\end{array}$ & $-1--$ & 84.29 & 91.39 & 90.16 & 94.34 \\
\hline
\end{tabular}

at elevations greater than 500 m, where temperatures are milder and rainfall is stronger and more evenly distributed during the year, such as the highlands of Ibiapaba (Ceará) and Diamantina (Bahia). This conjugation of elevation, temperature and rainfall regime favors the presence of the target species along with the forest formations that occur sporadically in the Caatinga biome, known as exception landscapes, humid islands (Ab'Sáber 2003) or mountain forests, which compose a fundamental niche for E. phyllantus in the biome, since it is common in the wetter parts of Brazil's Northeast region (Taylor \& Zappi 2004).

If the predicted climatic changes are confirmed, the models generated for the different future climate scenarios point to different arrangements in the potential distribution (good to high) of E. phyllantus in the Caatinga biome. Despite some differences in the spatio-temporal dimensions of the potential distribution, all the models projected contraction of the areas with greater potential (> 0.50) to the target species. This contraction outlook for cactus species has already been reported for other dry areas (arid and semiarid zones) with the advance of climate changes. Téllez-Valdés \& Dávila-Aranda (2003) and Dávila et al. (2013), in modeling the potential distribution this century of various cactus species in the Tehuacán-Cuicatlán biosphere (Mexico) in face of climate alterations, found that in the worst of the scenarios, all the species would face contraction of suitable areas. However, a contraction of potential areas as a result of climate changes is not the only response expected of cacti. Butler et al. (2012) 
evaluated the effects of three climate change scenarios of the IPCC for 2050 and 2080 on the distribution of Echinocereus reichenbachii on the Great Plains in the United States, and in all the scenarios investigated, the potential area increased in relation to the current situation. In turn, Cortes et al. (2014), studying the potential distribution of four cactus species in the Mexican state of Chihuahua under three IPCC scenarios and four time intervals (2000, 2020, 2050 and 2080), found a range of projections (contraction, stability and contraction).

The contraction effect obtained from the simulations for E. phyllantus may be an alert, by indicating a decline in the potential areas, and consequently possible local extinctions of the species in the Caatinga biome. This is the case of the meridional part of the biome (roughly from the border between the states of Pernambuco and Bahia southward), where the contraction in potential area (good to high) was drastic, leading to disappearance from these areas in the worst scenario (RCP8.5/2070). It is important to mention this since it allows inferring extinctions of other non-cactus epiphytes, such as orchids and bromeliads, which need similar habitats as E. phyllantus.

Regarding the remaining potential areas (good to high) of E. phyllantus in the worst scenario (RCP8.5/2070), two observations are important: 1) These areas tend to be concentrated in the northern part of Ceará, in the northernmost part of the biome, due to the presence of elevations higher than $500 \mathrm{~m}$ and location near the Atlantic Ocean, whence come strong winds carrying moisture throughout the year, thus guaranteeing the water (rain and dew) needed by the species; 2) When the Caatinga biome is projected for the future inserted in continental scale, its enclaves of humid forest formations disappear (Zanin et al. 2016), while in regional scale, like in this work, they persist.
Randin et al. (2009) showed that models with regional or local scale forecast persistence of adequate habitats, while models with larger scale indicate total loss, suggesting that projections with regional or local scale better reflect the possibility of species to tolerate climate change. Regional or local spatial scales better capture the environmental particularities (topographic diversity, local microclimates, habitats etc.), permitting observations and projections with greater biological realism (Bellard et al. 2012).

Brazilian biomes will suffer different impacts of climatic changes. The Amazon and Atlantic Forest biomes will be most affected due to the proportion of their areas covered by forest formations. In turn, the Caatinga biome should be among the least affected, given the dominance of open vegetation that may expand (Zanin et al. 2016). For this prediction about the Caatinga biome an addendum is warranted, namely that the expansion might be accompanied by erosion of biodiversity. The tendency for contraction of potential areas for $E$. phyllantus and thus of possible local extinctions in the biome is an indication. Moreover, local extinctions may occur of other plant species with similar environmental requirements to those of E. phyllantus.

Although it is very hard to obtain reliable predictions of the impacts of climate change on biodiversity, because this involves many uncertainties (Bellard et al. 2012), the tendency is for the reliability of the predictions to improve because the uncertainties are gradually being resolved with the use of new generations of algorithms, better biological information and more realistic future climate scenarios. Therefore, continued modeling of cactus species in this perspective and considering a biome with a trend for aridization are important to obtain predictions of impacts that can help guide future studies and more effective preventive measures. 


\section{Acknowledgments}

We authors are grateful for the PCI-DC scholarship provided by the Instituto Nacional de Pesquisas Espaciais/INPE.

\section{REFERENCES}

AB' SÁBER AN. 2003. Os Domínios de Natureza no Brasil: potencialidades paisagísticas. $2^{a}$ ed., São Paulo: Ateliê Editorial, $160 \mathrm{p}$.

ALBUQUERQUE UP ET AL. 2012. Caatinga revisited: ecology and conservation of an important seasonal dry forest. Sci World J 2012: 1-18.

ARAÚJO MB, THUILLER W \& PEARSON RG. 2006. Climate warming and the decline of amphibians and reptiles in Europe. J Biogeogra 33(10): 1712-1728.

BEAUMONT LJ, GALLAGHER RV, DOWNEY PO, THUILLER W, LEISHMAN MR \& HUGHES L. 2009. Modelling the impact of Hieracium spp. on protected areas in Australia under future climates. Ecograph 32(5): 757-764.

BELLARD C, BERTELSMEIER C, LEADLEY P, THUILLER W \& COURCHAMP F. 2012. Impacts of climate change on the future of biodiversity. Ecol Lett 15(4): 365-377.

BRASIL. 2016a. Ministério do Meio Ambiente. Plano Nacional de Adaptação à Mudança do Clima: estratégias setoriais e temáticas. Brasília: MMA 2: 295.

BRASIL. 2016b. Ministério do Meio Ambiente. Brasil: 5o Relatório Nacional para a Convenção Sobre Diversidade Biológica. Brasília: MMA, 240 p.

BUTLER CJ, WHEELER EA \& STABLER LB. 2012. Distribution of the threatened lace hedgehog cactus (Echinocereus reichenbachii) under various climate change scenarios. J Torrey Bot Soc 139(1): 46-55.

CAVALCANTE AMB. 2005. Jardins Suspensos no Sertão. Sci Am Brasil 32: 66-73.

CAVALCANTE AMB, MENEZES MOT \& MACHADO MC. 2013. Cactos do semiárido do Brasil: guia ilustrado. Campina Grande: Insa, 103p.

CAVALCANTE AMB \& VASCONCELOS GCL. 2016. Comércio legal de cactos ornamentais: oportunidade para uso sustentável no semiárido do Brasil. Ren 47(1): 9-19.

CORTES L, DOMÍNGUEZ I, LEBGUE T, VIRAMONTES O, MELGOZA A, PINEDO C \& CAMARILLO J. 2014. Variation in the distribution of four cacti species due to climate change in Chihuahua, México. Int J Environ Res Public Health 11(1): 390-402.
DALAPICOLLA J. 2016. Tutorial de modelos de distribuição de espécies: guia prático usando o MaxEnt e o ArcGIS 10. Laboratório de Mastozoologia e Biogeografia, UFES, Vitória. Disponível em: http://blog.ufes.br/lamab/ tutoriais. último acesso: Maio de 2017.

DÁVILA P, TÉLLEZ O \& LIRA R. 2013. Impact of climate change on the distribution of populations of an endemic Mexican columnar cactus in the Tehuacán-Cuicatlán Valley, México. Plant Biosyst 147(2): 376-386.

ELITH J \& LEATHWICK JR. 2009. Species Distribution Models: Ecological Explanation and Prediction Across Space and Time. Ann Rev Ecol Syst 40: 677-697.

FLORA DO BRASIL. 2020. EM CONSTRUÇÃO. Jardim Botânico do Rio de Janeiro. Disponível em: http://floradobrasil. jbrj.gov.br. (último acesso: Junho de 2017).

GBIF- GLOBAL BIODIVERSITY INFORMATION FACILITY. Disponível em: http://www.gbif.org. (último acesso: Fevereiro de 2017).

GIULIETTI AM, CONCEIÇÃO A \& QUEIROZ LP. 2006. Diversidade e caracterização das fanerógamas do semi-árido brasileiro. Recife: Associação Plantas do Nordeste 1: $488 \mathrm{p}$.

GUISAN A \& THUILLER W. 2005. Predicting species distribution: offering more than simple habitat models. Ecol Lett 8(9): 993-1009.

HIJMANS RJ, CAMERON SE, PARRA JL, JONES PG \& JARVIS A. 2005. Very high resolution interpolated climate surfaces for global land areas. Int J Climatol 25: 1965-1978.

IPCC - INTERGOVERNMENTAL PANEL ON CLIMATE CHANGE. $2014 \mathrm{a}$. Climate Change 2014: Synthesis Report. Contribution of Working Groups I, II and III to the Fifth Assessment Report of the Intergovernmental Panel on Climate Change [Core Writing Team, RK Pachauri \& LA Meyer (Eds)], IPCC, Geneva, Switzerland, 151 p.

IPCC - INTERGOVERNMENTAL PANEL ON CLIMATE CHANGE. 2014b. Climate Change 2014: Impacts, Adaptation, and Vulnerability. Part A: Global and Sectoral Aspects. Contribution of Working Group II to the Fifth Assessment Report of the Intergovernmental Panel on Climate Change [Field CB, Barros VR, Dokken DJ, Mach KJ, MD Mastrandrea, TE Bilir, M Chatterjee, KL Ebi, YO Estrada, RC Genova, B Girma, ES Kissel, AN Levy, S MacCracken, PR Mastrandrea, \& LL White (Eds)], Cambridge University Press, Cambridge, United Kingdom and New York, NY, USA 1: 1132 p.

IPCC - INTERGOVERNMENTAL PANEL ON CLIMATE CHANGE. 2014C. Climate Change 2014: Impacts, Adaptation, and Vulnerability. Part B: Regional Aspects. Contribution of 
Working Group II to the Fifth Assessment Report of the Intergovernmental Panel on Climate Change [Barros VR, CB Field, DJ Dokken, MD Mastrandrea, KJ Mach, TE Bilir, M Chatterjee, KL Ebi, YO Estrada, RC Genova, B Girma, ES Kissel, AN Levy, S MacCracken, PR Mastrandrea \& LL White (Eds)], Cambridge University Press, Cambridge, United Kingdom and New York, NY, USA 2: 688 p.

LACERDA FF, NOBRE P, SOBRAL MCM, LOPES GMB \& ASSAD ED. 2016. Tendência do clima do semiárido frente as perspectivas das mudanças climáticas globais; o caso de Araripina, Pernambuco. Rev Dep Geo USP 31: 132-141.

MARENGO JA. 2007. Mudanças climáticas globais e seus efeitos sobre a biodiversidade: caracterização do clima atual e definição das alterações climáticas para o território brasileiro ao longo do século XXI, $2^{\text {nd }}$ ed Serie Biodiversidade, Brasília: MMA 26: 212.

MARENGO JA. 2008. Vulnerabilidade, impactos e adaptação à mudança do clima no semi-árido do Brasil. Parc Estratégicas 13(27): 149-175.

MARENGO JA. 2014. O futuro clima do Brasil. Rev USP 103: 25-32.

MARENGO JA, TORRES RR \& ALVES LM. 2017. Drought in Northeast Brazil - past, present, and future. Theor Appl Climatol 129(3-4): 1189-1200.

MARTINELLI G \& MORAES MA. 2013. Livro vermelho da flora do Brasil. $1^{a}$ ed., Rio de Janeiro: JBRJ, 1100 p.

MMA - MINISTÉRIO DO MEIO AMBIENTE. Bioma Caatinga. 2017. Disponivel em: http://www.mma.gov.br/biomas/ caatinga. (último acesso: Maio de 2017).

OGAWA-ONISHI Y, BERRY PM \& TANAKA N. 2010. Assessing the potential impacts of climate change and their conservation implications in Japan: a case study of conifers. Biol Conserv 143(7): 1728-1736.

PBMC - PAINEL BRASILEIRO DE MUDANÇAS CLIMÁTICAS. $2014 \mathrm{a}$. Base Científica das Mudanças Climáticas. Contribuição do Grupo de Trabalho 1 do Painel Brasileiro de Mudanças Climáticas ao Primeiro Relatório de Avaliação Nacional sobre Mudanças Climáticas. [Ambrizzi T \& Araujo M (Eds)]. Rio de janeiro, Coppe/Universidade Federal do Rio de Janeiro, $464 \mathrm{p}$.

PBMC - PAINEL BRASILEIRO DE MUDANÇAS CLIMÁTICAS. 2014b. Impactos, Vulnerabilidades e Adaptação às Mudanças Climáticas. Contribuição do Grupo de Trabalho 2 do Painel Brasileiro de Mudanças Climáticas ao Primeiro Relatório da Avaliação Nacional sobre Mudanças Climáticas. [Assad ED \& Magalhães AR (Eds)]. Rio de Janeiro, Coppe/Universidade Federal do Rio de Janeiro, $414 \mathrm{p}$.
PEARSON RG \& DAWSON TP. 2003. Predicting the impacts of climate change on the distribution of species: are bioclimate envelope models useful? Global Ecol Biogeogr 12(5): 361-371.

PETERSON AT, PAPES M \& KLUZA DA. 2003. Predicting the potential invasive distributions of four alien plant species in North America. Weed Sci 51(6): 863-868.

PHILLIPS SJ, ANDERSON RP \& SCHAPIRE RE. 2006. Maximum entropy modeling of species geographic distributions. Ecol Model 190(3-4): 231-259.

RANDIN CF, ENGLER R, NORMAND S, ZAPPA M, ZIMMERMANN NE, PEARMAN PB, VITTOZ P, THUILLER W \& GUISAN A. 2009. Climate change and plant distribution: local models predict high-elevation persistence. Global Change Biol 15(6): 1557-1569.

REDDY SJ. 1993. Climatic classification: the semiarid tropics and its environment - a review. Pesq Agropec Bras 18(8): 823-847.

RODAL MJN \& SAMPAIO EVSB. 2002. A vegetação do bioma caatinga. In: Sampaio EVSB et al. (Eds), Vegetação e flora da Caatinga, Recife: PNE/CNIP, Recife, BRA, p. 11-14.

SALES DC ET AL. 2015. Projeções de mudanças na precipitação e temperatura no nordeste brasileiro utilizando a técnica de downscaling dinâmico. Rev Bras Meteorol 30(4): 297-308.

SAMPAIO EVSB. 2003. Caracterização da caatinga e fatores ambientais que afetam a ecologia das plantas lenhosas. In: Sales VC et al (Eds), Ecossistemas brasileiros: manejo e conservação, Fortaleza: Expressão Gráfica Editora, Fortaleza, BRA, p. 129-142.

SAMPAIO EVSB. 2010. Caracterização do bioma Caatinga: características e potencialidades. In: Gariglio MA et al. (Eds), Uso sustentável e conservação dos recursos florestais da Caatinga, Brasília: SFB, Brasília, BRA, p. $29-48$.

SANTOS MG ET AL. 2014. Caatinga, the Brazilian dry tropical forest: can it tolerate climate change? Theor Exp Plant Physiol 26(1): 83-99.

SEDDON AW, MACIAS-FAURIA M, LONG PR, BENZ D \& WILLIS KJ. 2016. Sensitivity of global terrestrial ecosystems to climate variability. Nature 531(7593): 229-232.

SPLINK. Centro de Referência em Informação Ambiental. 2016. Disponível em: http://splink.cria.org.br. (último acesso : Junho de 2016).

STOHLGREN TJ, MA P, KUMAR S, ROCCA M, MORISETTE JT, JARNEVICH CS \& BENSON N. 2010. Ensemble habitat mapping of invasive plant species. Risk Anal 30(2): 224-235. 
TAYLOR N \& ZAPPI D. 2004. Cacti of Eastern Brazil. Richmond, Kew: The Royal Botanic Gardens, 499 p.

TÉLLEZ-VALDÉS O \& DÁVILA-ARANDA P. 2003. Protected areas and climate change: a case study of the cacti in the Tehuacán-Cuicatlán Biosphere Reserve, México. Conserv Biol 17(3): 846-853.

THUILLER W, BROENNIMANN O, HUGES G, ALKEMADE JRM, MIDGLEY GF \& CORSI F. 2006. Vulnerability of African mammals to anthropogenic climate change under conservative land transformation assumptions. Glob Chang Biol 12(3): 424-440.

VAN VUUREN DP ET AL. 2011. The representative concentration pathways: an overview. Clim Change 109(5): 5-31.

WARREN DL, WRIGHT AN, SEIFERT SN \& SHAFFER HB. 2014. Incorporating model complexity and spatial sampling bias into ecological niche models of climate change risks faced by 90 California vertebrate species of concern. Diversity Distrib 20(3): 334-343.

YANGX-Q, KUSHWAHA SPS, SARAH S, XU J \& ROY PS. 2013. Maxent modeling for predicting the potential distribution of medicinal plant, Justicia ad hatoda L. in Lesser Himalayan foothills. Ecol Eng 51: 83-87.

ZANIN M, TESSAROLO G, MACHADO N \& ALBERNAZ ALM. 2016. Mudanças climáticas e a cobertura vegetal nativa: impactos em um pais megadiverso e seus biomas. In: Teixeira BS et al. (Eds), Modelagem climática e vulnerabilidades setoriais à mudança do clima no Brasil, Brasília: MCTIC, Brasília, BRA, p. 93-125.

\section{How to cite}

CAVALCANTE AMB, DUARTE AS \& OMETTO JPHB. 2020. Modeling the potential distribution of Epiphyllum phyllanthus (L.) Haw. under future climate scenarios in the Caatinga biome. An Acad Bras Cienc 92: e20180836. DOI. 10.1590/0001-3765202020180836.
Manuscript received on August 10, 2018;

accepted for publication on Febuary 2, 2019

\section{ARNÓBIO M.B. CAVALCANTE ${ }^{1}$}

https://orcid.org/0000-0001-5541-6677

\section{ARYBERG S. DUARTE}

https://orcid.org/0000-0002-4867-6240

\section{JEAN PIERRE H.B. OMETTO ${ }^{2}$}

https://orcid.org/0000-0002-4221-1039

${ }^{1}$ Instituto Nacional de Pesquisas Espaciais, Centro Regional do Nordeste/Unidade de Eusébio, Estrada do Fio, 6000, Tupuiu, 61760-000 Eusébio, CE, Brazil

${ }^{2}$ Instituto Nacional de Pesquisas Espaciais, Centro de Ciência do Sistema Terrestre, Av. dos Astronautas, 1758, Jardim da Granja, 12227-010 São José dos Campos, SP, Brazil

Correspondence to: Arnóbio de Mendonça Barreto Cavalcante E-mail:arnobio.cavalcante@inpe.br

\section{Author contributions}

Cavalcante AMB idealized and developed this study, performed the analysis, interpreted the results and worked on the manuscript. Duarte AS processed the data and built the models. Ometto JPHB contributed to the discussion and text revision.

\section{(cc) BY}

